Научна критика

УДК 821.163.41.09-14:398(049.32)

Примљен: 4. марта 2021.

Прихваћен: 5. марта 2021.

https://doi.org/10.46630/phm.13.2021.65

\title{
ИСТОЧНИК МАГИЈСКОГ
}

(Јасмина Јокић, Магијско извориште поетског - огледи о усменој лирици. Нови Сад: Филозофски факултет, 2019)

Крајем 2019. године објављена је књига проф. др Јасмине Јокић Магијско извориште поетског - огледи о усменој лирици. Она представља збирку студија посвећених разноврсним проблемима усмене лирике и изузетно је значајан прилог изучавању лирске народне поезије српског народа, као и његове традиције и културе. Вредности студија које су доминантно усмерене ка обредној поезији и магијским наративима уочавају се на више планова: од разноврсности тематике, интересовања за више усмених лирских врста, увида у шире територијалне оквире, до приступа истраживачком материјалу и примене одговарајућих теоријско-методолошких поставки и аналитичког апарата.

Девет поглавља ове књиге (Од иявета до плода: женски иницијаиијски пут у српској обредној тирици, Жена као носилаи магијске моћи у календарским ритуалима и поезији, Ритуални плач у свадбеној поезији Срба са Косова и Метохије, Црне очи- два бистра кладенца: култ извора у усменој поезији, Кад се Христос на земль родио: рођење и критене Исуса Христа у фолклорној традицији, Митска изворишта мотива о играюу/титрағу јабуком у усменој тириии, Обредна позадина једне дечије песме (Умре, умре, Рајоле), Мотив ванбрачног детета у басмама против града: текст и контекст, Ослептивате змије у јеремијским песмама: од магијско-ритуалне праксе до поетског текста) обједињује наслов којим се истиче усмереност аутора ка уочавању битних елемената настајања, извођења, пријема и функционисања лирске народне поезије.

Поетски елементи обликовани архаичним представама о улози женског принципа у постојању и развоју вегетације (жена као носилац магијских способности и она која утиче на биљни свет) у средишту су пажње истраживача у поглављу које „отвара“ расправу о магијском као подлози фолклора и неких фолклорних жанрова (Од ивета до плода: женски иницијацијски пут у српској обредној тирици). Ауторка издваја песме у којима запажа овакву подлогу, а пажњу нарочито посвећује лазаричким, краљичким и свадбеним песмама. Указујући на специфичност 
њиховог жанровског функционисања (календарски и животни циклус), она проучава различите елементе, пре свега поетску слику, изражајне облике формулативног исказа који учествују у њеном обликовању, али се истовремено истичу обредни контекст и веровања (ритуална купања, поступање са биљкама итд).

Архаична подлога манифестована у рецепцији жене као бића блиског оностраном одредила је и неке врсте песама годишњег циклуса. У поглављу Жена као носилац магијске моћи у календарским ритуалима u поезији етнолошка и етнографска грађа поуздан су оквир истраживањима поетских облика. Њима се формира мање или више потпуна слика одговарајућег обредног контекста у чијим се оквирима изводе поједине песме - краљичке, лазаричке, додолске, са елементима представа и веровања о жени као носиоцу магијске моћи.

У поглављу Ритуални плач у свадбеној поезији Срба са Косова u Mетохије истражује се мотив ритуалног плача у свадбеним песмама. Систематизујући сазнања из разноврсне литературе (етнографске, етнолошке, културноисторијске), као специфичност ове врсте лирских народних песама са простора Косова и Метохије Јокић издваја обредно тужење у његовим различитим формама: од гласног јадиковања/ плакања до певања песама баладичне интонације и оних у којима се запажају елементи тужбалица. Повезаност са тужбалицом, доминантно у тематскомотивском слоју, нарочито је одликовала старије записе. Ово је упутило на закључак о израженој архаичности овог материјала и, у том смислу, другачијег у односу на класични корпус у записима Вука Караџића. Регистровани су елементи обредног комплекса праћени усменим облицима блиским тужбалици, а уочени су у различитим његовим сегментма: пре свадбе, приликом доласка по невесту, на путу између невестине и младожењине куће. Описан је тематско-мотивски слој и указано на његово сагласје са обредом прелаза, његовим значењем и функцијом.

Мотив претварања очију у извор воде анализиран је у варијантама песама о оклеветаној сестри (Бог ником дужан не остаје, Вук Караџић, Српске народне пјесме II). Древне представе о повезаности очију и воде рефлектоване су у неколиким усменим жанровима (загонетка, пословица, неке врсте обредних и обредно-обичајних песама, предања), али и делима писане књижевности. У њима је, закључује се, „сачувана древна симболика извора као главног облика тзв. живе воде [...] која је одувек сматрана праузором сваке воде“.

Проблему трансформације и адаптације теолошког наратива о Христовом рођењу у народној традицији посвећено је поглавље Кад се Христос на землу родио: рођене и критене Исуса Христа у фолклорној mрадицији. Прожимање хришћанског и паганског посматрано је нарочи- 
то на грађи лирских усмених песама о рођењу и крштењу Христа. Темељени на старијим слојевима мишљења, мотиви и поетске слике показују комплексне слојеве у настајању и обликовању усменоуметничког израза. Ауторка упућује на шири контекст, сегменте новозаветних текстова, веровања и представе, пратећи их према следећим мотивима: најава рођења у сну, отварање небеса, рађање и слично.

Мотивом играња (златном) јабуком Јокић се бави у поглављу под насловом Митска изворишта мотива о играғу/титрағу јабуком у усменој лирици. Региструјући га у митолошким, краљичким, лазаричким љубавним песмама, она анализу заснива на полазишту које подразумева могућност да његову основу представљају веровања о магијском утицају утицају на „метеоролошке појаве извођењем одређених ритуалних радњи“.

Обредни контекст песме из збирке Вука Караџића, као и неколико њених варијаната, у средишту су интересовања у поглављу Обредна позадина једне дечије песме (Умре, умре, Рајоле). Одређени су кључни мотиви у песми (смрт, припрема за сахрану, сахрана), идентификоване измене на више нивоа (на нивоу персоналног, предметног, акционалног кода). Забележена повезаност вербалног са акционалним, по мишљењу ауторке, упућује на обредно порекло игре која је, временом, прошла кроз процес деградације и профанације те перципирана као дечја игра у функцији забаве. Поред тога, на основу постојања сродних елемената овог обреда са обредима за изазивање кише (Герман) закључује се о њиховом могућем заједничком пореклу и функцији.

Условљеност вербалног исказа обредним радњама, веровањима и представама као њиховој подлози, у ширем смислу предмет су проучавања у раду Мотив ванбрачног детета у басмама против града: текст и контекст. Уже, овај проблем истражује се на мотиву запаженом у басмама против града. Сложени системи веровања о статусу ванбрачног детета обликовали су основне елементе готово свих обредних кодова. Два облика реализације овог мотива (грађени на негативној и позитивној перцепцији ванбрачног детета у традицијској свести) обликују различите типове бајаличког текста, чије извођачке контексте одликује и различит темпорални код.

Књига се завршава студијом Ослепљивағе змије у јеремијским песмама: од магијско-ритуалне праксе до поетског текста. Њу чине увод и два самостална сегмента: Ритуално ослепливаюе змије и юена повезаност са очима и видом и Забране женских радова на змијске празнике. У првом се прате ритуалне манифестације за ослепљивање (инхибицију и деструкцију) змија, практиковане о Јеремијиндану, Тодоровој и Лазаревој суботи, и уочава њихов семантички потенцијал повезан са усменоу- 
метничким творевинама (пре свега јеремијским песмама и басмама). У другом делу, истакнуте су забране у контексту змијских празника, чија се хтонска природа уочава у разним елементима ритуалног (време обављања - јутро, пре изласа сунца; забрана о задушницама и слично) и поетског. У везу са истовременом забраном додиривања игала и њиховом употребом у обредној манифетацији Јокић доводи и амбивалентну природу змије у традицијским оквирима.

Нове прилоге проучавању фолклора Јасмина Јокић писала је поуздано, прецизно, применом актуелних и релевантних теоријско методолошких поставки. Веома сложеним проблемима утврђивања архаичних представа у оквирима усменоуметничког израза приступљено је са намером да се представи и шири контекст, нарочито онда када се говорило о о проблемима обредне и обредно-обичајне поезије. Остварење такве намере омогућио је увид у изузетно обимну литературу, домаћих и страних истраживача (доминантно руске и бугарске фолклористике), дијахрону и синхрону, што се може сматрати посебним квалитетом ових истраживања. Мада се бави лирском усменом поезијом, ауторка не оставља по страни и, релевантне за њено истраживање, поетске одлике других усмених жанрова. Научно утемељена проучавања Јасмине Јокић и њихови резултати омогућавају нове увиде у облике, семантику и функционисање усмене лирске поезије Срба. У том смислу, позивају на читање, промишљање и осврте, позивају не само оне који се фолклором речи баве са научних гледишта, већ и оне којима је уметност усмене речи занимљиво, динамично и витално источиште грађе естетских и ванестетских функција и студија о њој.

Данијела Поповић Николић

Универзитет у Нишу Филозофски факултет Департман за Србистику danijela.popovic.nikolic@filfak.ni.ac.rs 